Journal of Contemporary Research in Business, Economics and Finance

ISSN: 2641-0265

Vol. 2, No. 1, pp. 18-28

2020

Publisher: Learning Gate

DOI: 10.33094/26410265.2020.21.18.28

(C) 2020 by the authors; licensee Learning Gate

\title{
Sectorial Allocation of Bank Credits and Economic Development in Nigeria
}

\author{
Abina, Adedigba Praise \\ Finance \& Banking Department, University of Port Harcourt, Port Harcourt, Nigeria. \\ Email:praise2009@yahoo.com
}

Received: 16 June 2020; Revised: 20 July 2020; Accepted: 7 August 2020; Published: 26 August 2020

\begin{abstract}
This study examines sectorial allocation of bank credits and economic development in Nigeria. The study made use of human development index as proxy for dependent variable measuring economic development while bank credits to public sector, manufacturing, agricultural, mining general commerce sector, real estate and construction, was used in the study as independent variables. All data were obtained from Central Bank of Nigeria statistical bulletin and index-mudi which span across 1985 to 2019. Data stationarity was ensured using the Augmented Dickey Fuller statistics, while the error correction model was applied to as the statistical tool for acceptance of hypothesis. The results of the analysis showed that bank credits to manufacturing, mining and general commerce sector contributed negatively to human development index while bank credit to public sector, real estate and agricultural sector contributed positively to human development index. The study also upholds the bank-based systems and that of the commercial bank theory. The current risky business environment is affecting banks' ability to lend to the manufacturing, mining and general commerce sector which ought to drive development. This study recommends that monetary authorities should control key macro-economic factors; this will enable the banking sector to create more credit for the economy. Thereby enhancing investment and employment opportunities which on the other hand will boast economic development in the country.
\end{abstract}

Keywords: Bank, Lending, Sector, Allocation, Loan.

JEL Classification: C22; E22; G21; R38; P33.

\section{Introduction}

Banks are organized financial institutions that undertake the activity of savings and extending credit facilities to various economic units, having a dual effect on the economy and the banking institutions at large. The disequilibrium identified between various economic agents is bridged by the intermediation activity that financial institutions undertakes in the economy. The loan extended by the banks generate interest which serves as income to meet their various expenditure and shareholder's needs, the interest directly or indirectly affects bank performance on the long run. According to Ezirim (2005) bank extend credit to deficit economic unit in order to meet their financing need. This credit can be classified into short term, medium term and long-term basis, while it can be sub-classified into manufacturing credit, agricultural credit, industrial credit and personal loans; all these directly and indirectly affect return on asset of banks. According to Bebeji (2010) the time frame of an investment to be undertaken determines the nature of risk that is attached to such investment, an investment is said to be riskier when the time frame of credit repayment is long in comparison with that of a short-term basis. Okereke (2003) ascertained that emergence of bank and the banking business is a deliberate and conscious effort of the modern man to bridge the gaps associated with an un-intermediated economy. Allocating and mobilization of financial resources is one of the primary roles of financial institutions most especially the banking sector which wield tremendous influence on every nation, this is done via direct credit or by real and financial asset investment. The monetary authority of developing nations 
focuses primarily on the banking sector because of their influence in pooling funds and extending credit to the economy, in a bid to ensuring that development projects like agricultural activities, industrial housing and commercial activities in the economy are well funded. According to Nwakanma, Nnamdi, and Omojefe (2014) the productive sector of the economy are allocated loan and advances, this function is underscored by the banks' ability to mobilize savings from the public which ensures that projects that facilitates development are funded properly. Moreover, the amount of loanable fund accessible, determine the supply of credit that is made available by the banking sector to the government, institutions and individuals. Loanable fund is composed of savings from individuals, firms and various actions of depository institutions in the financial market. The work of Odufuye (2007) attest that planned savings and accumulated savings cumulatively sums up to be loanable fund which eventually will lead to capital formation. Access to loan still remain one of the basic problems faced by most sector, despite the loans allocated to various sectors in Nigeria, the procedure of securing this loan facilities is cumbersome, the collateral requirements and criteria requested by the loan officer is so stressful that they give up the process along the line (Nzomoi \& Rutto, 2012). The shortage of fund has constrained productivity leading to low level of investments and development setbacks (Anyanwu, 2000). Banks unwillingness to make fund available to the manufacturing sector is due to the mis-match between the short-term, medium and long-term nature of funds needed by industries (Franklin \& Oura, 2004).

The production capacity of firm is limited to the machine they have at hand, firms face a big challenge in securing new machine and information technology. Because of insufficiency in funds, this pose a major challenge to the firm's production capacity resulting to underproduction and as a result increase production cost and weakens competitiveness in the country. In Nigeria, banks prefer to lend to low risk ventures; the mining sector and manufacturing sector are perceived to be high-risk venture, and as such, they are very mindful on how they lend to them. Banks prefer to lend to the commercial and agricultural sector because of the low risk perceived in that sector. According to Nwanyanwu (2011) productive sector credit is weak in stimulating growth because it is prone to waste and embezzlement, he also pointed out that politically motivated programmes does not deliver the best results because of imbedded embezzlement. Sebastian (2018) discovered that the cost, quality and quantity of credit has limited self-employment and other channel of creating jobs, the expansion of businesses are constrained by the availability of loanable funds. The informal sector of the economy still holds substantial proportion of credit transactions despite all the effort government place in making credit available to the productive sector through development banks and deposit money banks (DMBs).

\section{Theoretical Review}

\subsection{Theory of Bank-Based Financial System}

This theory posits that banks plays vital role in the development process of any nation. In developing economy, the bank has more prospect to financing developmental project more than any other financial institution in the state. According to Levine (2002); Singh (1997) agency problem and that of asymmetric information arises as a result of market imperfection, which can be fixed with the introduction of the bank-based systems this helps in fixing resource allocation problems. The information sourced by investors is revealed publicly, at little, or no cost in a well-developed market, the bank-based system mitigates the risk and loss involved in seeking and acquiring additional information by investors.

\subsection{Financial Intermediation Theory}

McKinnon (1973) and Shaw (1973); Goldsmith (1969) discovered that the financial market plays an essential role in economic development. The level of development is dependent on the quality and quantity of services provided by the financial institutions in the country. Financial institutions help in bridging the gap between surplus spending unit and deficit spending unit by making fund available to deficit unit at a reasonable amount which helps in making capital available for further production to take place thereby propelling the growth process in the country's financial markets. Goldsmith (1969) 
pointed out that development in any country is dependent on how financial institutions encourage efficient use of capital stock.

\subsection{Commercial Loan Theory}

This theory is also known as the real bill doctrine, this theory opined that banks need to lend short since the various deposit collected is short in nature. This theory argue that self-liquidating and productive loan should be granted to customers. The main reason behind this postulation is that, for banks to meet various demand deposit liabilities whenever it's called upon to be paid, then they ought to lend short. This theory is also linked with that of the orthodox theory of banking, this theory limits banks to commercial transaction only on short term basis, the theory stress that lending short will help in making the bank willing and ready to meet depositors demand.

\subsection{Conceptual Review}

\subsubsection{How Banks Lends}

Deposit taken institutions allocate credit to different sectors in the economy in the form of loans and advances which is gotten from the pool of fund they get from their customers. The capacity of funds mobilised underscores their capacity to effectively allocate these funds to various users in the economy. Various projects like that of agricultural, housing, commercial and industrial activities will be funded through this means. Banks' lending function is directly related to economic growth since they are the largest deposit taking financial institution in Nigeria. The banks help in closing the gap identified between the lenders and the borrowers, this gap is closed by creating a market that accommodates two types of security which suit the two categories of persons identified earlier. In Nigeria, banks are major player in capital formation process because of their ability to secure high volume of capital at a faster rate, they help in providing capital for production to expand, they also help in facilitating bills payment when it comes to international trade on a faster rate, their involvement in technology and innovation has also made it possible for the economy to develop.

\subsection{Empirical Review}

Nwakanma et al. (2014) investigated the direction and long run relationship between private sector and bank credit, Granger Causality and Autoregressive Distributed Lag Bound (ARDL) was used for statistical analysis and it was concluded that long run relationship and causality exist between bank credits and loan given to the private sector. Adesoye, Adelowokan, Maku, and Salau (2018) examined agriculture value chain and economic diversification, the data for the study was gotten from 1981-2015. After making use of autoregressive distributed lag, it was discovered that substantial relationship is attainable between agricultural expenditure and agricultural sector output in Nigeria, albeit capital and labour also affect output directly. The study recommends that institutions that will inculcate agriculture programmes. Bank credit and agricultural sector output was examined by Ekine and Onukwuru (2018) the study made use of error correction model as the analytical tool, significant relationship was discovered between bank credit, interest rate and agricultural expenditure on agricultural sector output. Thus, the study recommends that government and private individual should make effort to invest more in agricultural activities. Andabai and Eze (2018) examined the causal relationship between bank credit and manufacturing sector output, the study made use of time series data from 1990-2016, it was discovered after using vector error correction model and causality test that there is no causal relationship between bank credit and manufacturing sector output. The study further suggests that reduced interest rate with favourable inflation rate will stimulate manufacturing sector output which should be regulated by the needed authorities. Michael, Babatunde, and Joseph (2017) investigated how bank loan affect the manufacturing sector in Nigeria, the study made use of time series data from 19992014. Autoregressive Distributed Lag (ARDL) was used as the statistical tool for analysis, it was discovered that financial institution credit increases output in the manufacturing industry. The study 
concluded that if output was to increase then financial institution is required to place more priority to the financial needs of private sector; thus, manufacturing sector output will increase.

\section{Research Methodology}

In order to study the relationship between Sectorial allocation of bank credits and economic development in Nigeria. The data for the study will be gathered from World Bank data base and statistical bulletin of Central Bank of Nigeria (CBN, 2020).

\subsection{Method of Data Analysis}

The first step consists of analysing the stationarity or the integration of the variables engaged in the model using the Augmented Dickey-Fuller test statistic, then to apprehend the long run association between the 6 variables, we will run the Johansen Cointegration Test. After admitting the integration and the long run association of all the variables, we will then be able to move to the last step that is to conduct the causality test and then the Error Correction Model (ECM).

\subsection{Model Specification}

The model used in this research is specified in three forms.

\section{The Functional Form of the Model:}

HDI= F (BCTPS, BCTREC, BCTMFS, BCTAS, BCTMS, BCTGC) (1)

The Equation 1 above shows the functional relationship between the dependent and independent variable, it is imperative to include the estimation parameters; thus, we rewrite the Equation 1 as follows:

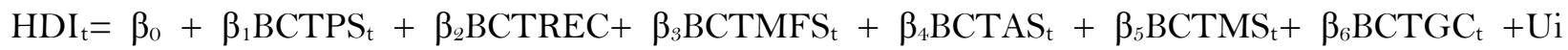
(2)

Apriori: $\beta_{1}>0, \beta_{2}>0, \beta_{3}>0 \beta_{4}>0, \beta_{5}>0, \beta_{6}>0$

For estimation purpose the Equation 2 above shows the econometric form of Equation 1.

Where,

HDI $=\quad$ Human Development Index

BCTPS $=\quad$ Bank Credit to Public sector

BCTREC $=$ Bank Credit to Real Estate and Construction

BCTMFS $=$ Bank Credit to Manufacturing Sector

BCTAS $=\quad$ Bank Credit to Agricultural Sector

BCTMS $=$ Bank Credit to Mining Sector

BCTGC $=$ Bank Credit to General Commerce Sector

$\beta_{\mathrm{o}}=\quad$ constant or intercept

$\mathrm{Ui}=\quad$ error term

$\beta_{1},>\beta_{6}=\quad$ estimation parameters for the respective independent variables.

\subsection{Apriori Expectation}

Based on the theories earlier stated it is expected that each of the variables should cause a positive change in the dependent variable, this is estimated via the apriori expectation sign below. In the specified model, the expected relationship is that bank credit to manufacturing, agricultural, mining, public sector, real estate and construction and general commerce sector will have individual positive impacts on human development index (HDI). In summary, it is anticipated that increase in credit disbursement should spur up economic development in Nigeria. 


\section{Data Analysis and Interpretation of Result \\ 4.1. Descriptive Statistics}

Table 1.

Presentation of descriptive statistics result

\begin{tabular}{c|c|c|c|c|c|c|c}
\hline & HDI & BCTPS & BCTREC & BCTMFS & BCTAS & BCTMS & BCTGC \\
\hline Mean & 0.523088 & 667871.4 & 18506.79 & 66093.45 & 18063.34 & 900.5941 & 40336.68 \\
\hline Median & 0.527500 & 42.99500 & 2.950000 & 220.1800 & 48.97500 & 23.76500 & 0.750000 \\
\hline Maximum & 0.670000 & 22708225 & 622776.2 & 2230155. & 610149.7 & 20691.07 & 1362578. \\
\hline Minimum & 0.420000 & -3107.690 & 0.000000 & 3.230000 & 1.310000 & 0.000000 & 0.000000 \\
\hline Std. Dev. & 0.058288 & 3894432. & 106772.1 & 382380.5 & 104619.1 & 3541.552 & 233634.5 \\
\hline Skewness & 0.232625 & 5.570484 & 5.570414 & 5.570459 & 5.570463 & 5.357462 & 5.570452 \\
\hline Kurtosis & 3.072793 & 32.03029 & 32.02979 & 32.03012 & 32.03015 & 30.44754 & 32.03007 \\
\hline Jarque-Bera & 0.314154 & 1369.745 & 1369.700 & 1369.729 & 1369.732 & 1229.917 & 1369.725 \\
\hline Probability & 0.854638 & 0.000000 & 0.000000 & 0.000000 & 0.000000 & 0.000000 & 0.000000 \\
\hline Sum & 17.78500 & 22707629 & 629231.0 & 2247177. & 614153.4 & 30620.20 & 1371447. \\
\hline Sum Sq. Dev. & 0.112117 & $5.00 \mathrm{E}+14$ & $3.76 \mathrm{E}+11$ & $4.83 \mathrm{E}+12$ & $3.61 \mathrm{E}+11$ & $4.14 \mathrm{E}+08$ & $1.80 \mathrm{E}+12$ \\
\hline Observations & 34 & 34 & 34 & 34 & 34 & 34 & 34 \\
\hline
\end{tabular}

From the above, Table 1 shows the descriptive statistics result; It can be seen that BCTPS has the highest mean 667871.4, followed by BCTMFS with the mean of 66093.45, then BCTGC with 40336.68, BCTREC with the mean of 18506.79 and others followed, BCTREC, BCTAS and HDI with the lowest mean. Median: HDI has the lowest median value of 0.527500 , followed by BCTGC having 0.750000, then BCTREC has 2.950000, while BCTMFS has the highest median 220.1800. Minimum: BCTMFS has the highest minimum 3.230000, followed by BCTAS 1.310000 , then a negative minimum which is 3107.690 of BCTPS. Standard Deviation: BCTPS has the highest standard deviation 3894432., followed by BCTMFS 382380.5 then 3541.552 for BCTMS, BCTGC, BCTREC and BCTAS finally HDI with 0.058288. Skewness: The highest is BCTPS 5.570484, followed by BCTMS 5.570459, then BCTREC 5.570414, BCTGAS 5.570463, BCTAS 5.570463, BCTGC 5.570452 BCTMS 5.357462 finally HDI with 0.232625. Kurtosis: BCTPS with 32.03029 has the highest kurtosis value followed by BCTMFS with 32.03012 value, followed by BCTAS 32.03015, BCTGC 32.03007, BCTREC 32.02979 BCTMS 30.44754 then lowest is that of HDI with 3.072793. Probability: It was discovered that only HDI was found to be insignificant.

\subsection{Stationarity Test}

Before estimating Equation 1 this study examines the stationary status of the variables to ensure appropriate regression estimate. The stationary test was carryout using the Augmented Dickey Fuller test. From the stationarity estimates presented in Table 2 below, it was observed that all the variables are integrated of order one, that is, the variables are I (1) series.

Table 2.

Presentation of augmented dickey-fuller (ADF).

\begin{tabular}{|c|c|c|c|c|c|c|}
\hline \multirow[t]{2}{*}{ Variable } & \multirow{2}{*}{$\begin{array}{l}\text { ADF test } \\
\text { statistic }\end{array}$} & \multicolumn{3}{|c|}{ Critical Value 5\% } & \multirow[t]{2}{*}{$\begin{array}{c}\text { Order of } \\
\text { Integration }\end{array}$} & \multirow[b]{2}{*}{ Prob. } \\
\hline & & $1 \%$ & $5 \%$ & $10 \%$ & & \\
\hline D(HDI) & -7.047888 & -3.653730 & -2.957110 & -2.617434 & $\mathrm{I}(1)$ & 0.0000 \\
\hline D(BCTPS) & 4.052911 & -3.737853 & -2.991878 & -2.635542 & $\mathrm{I}(1)$ & 0.0012 \\
\hline D(BCTREC) & 6.036335 & -4.582648 & -3.320969 & -2.801384 & $\mathrm{I}(1)$ & 0.0001 \\
\hline D(BCTMFS) & 3.862002 & -3.679322 & -2.967767 & -2.622989 & $\mathrm{I}(1)$ & 0.0016 \\
\hline $\mathrm{D}$ (BCTAS) & 5.275608 & -3.737853 & -2.991878 & -2.635542 & $\mathrm{I}(1)$ & 0.0001 \\
\hline D(BCTMS) & -5.403099 & -4.728363 & -3.759743 & -3.324976 & $\mathrm{I}(1)$ & 0.0191 \\
\hline $\mathrm{D}$ (BCTGC) & 12.47952 & -4.582648 & -3.320969 & -2.801384 & $\mathrm{I}(1)$ & 0.0001 \\
\hline
\end{tabular}


From the Table 2 analysis above, it was discovered that the variables attain stationarity at order one 1(1), the outcomes of the variables revealed that the t-statistic of the HDI, BCTPS BCTREC BCTMFS BCTAS BCTMS BCTGC were variable is, which is > (greater) than the critical values at $1 \%, 5 \%$ and $10 \%$ levels.

\subsection{Co-Integration Test}

Table 3.

Johansen Co-Integration Test.

\begin{tabular}{|c|c|c|c|c|}
\hline \multicolumn{5}{|c|}{ Unrestricted Cointegration Rank Test (Trace) } \\
\hline Hypothesized & & Trace & 0.05 & \\
\hline No. of CE(s) & Eigenvalue & Statistic & Critical Value & Prob.** \\
\hline None ${ }^{*}$ & 0.996136 & 506.2625 & 150.5585 & 0.0000 \\
\hline At most $1 *$ & 0.985876 & 328.4706 & 117.7082 & 0.0000 \\
\hline At most $2 *$ & 0.887026 & 192.1535 & 88.80380 & 0.0000 \\
\hline At most $3 *$ & 0.818868 & 122.3743 & 63.87610 & 0.0000 \\
\hline At most $4 *$ & 0.704670 & 67.70129 & 42.91525 & 0.0000 \\
\hline At most $5^{*}$ & 0.470794 & 28.67212 & 25.87211 & 0.0218 \\
\hline At most 6 & 0.228660 & 8.308040 & 12.51798 & 0.2275 \\
\hline
\end{tabular}

Note: Trace test indicates 6 cointegrating eqn(s) at the 0.05 level.

* denotes rejection of the hypothesis at the 0.05 level.

As a follow-up to the stationary tests, this study examines the presence of co-integration among the variables in Equation 1. The co-integration test was estimated using the Johansen co-integration test and the result is presented in Table 3. The Trace and Maximum Eigen value tests clearly reveal the presence of one co-integration equation among the variables. Both tests rejected the null hypothesis of no co-integration for $\mathrm{r}=\mathrm{O}$ at five percent critical values while the null hypothesis of no co-integration for $r \leq 1$ at five percent critical value could not be rejected. This is because the statistic values for both tests at $r \leq 1$ were less than the critical values at five percent. The co-integration result suggests that six (6) cointegrating equation is seen in the Table 3 above this suggest that the linear combination of the variables is stationary and there exists a long run relationship among the variables.

\subsection{Error Correction Model Estimates (ECM)}

The presence of co-integration necessitates the need to check for adjustment between the short run and the long run.

\subsection{Global Statistics}

The ECM coefficient is -0.418358 and has a probability value of 0.0330 , thus confirms that ECM value is indeed significant. This implies that $42.0 \%$ deviations from disequilibrium in previous year can be adjusted in the current year. The negative sign of coefficient indicates convergence in short run model. ECM coefficient is relatively lower and indicates that short run dynamics of human development index gradually adjusts to long run equilibrium. The coefficient of determination ( $\mathrm{R}$ squared) from the results presented indicates that the independent variables contributed 0.580393 to human development index) over the period under review with the significant level of 0.001303 which is less than 0.05 indicating that the independent variables are making a unique contribution to economic development in Nigeria.

\subsection{Relative Statistics}

The result in Table 4 shows that bank credit to public sector exhibited a positive coefficient of 4.000126 alongside an insignificant $\mathrm{P}$-value of 0.0771 which is greater than 0.05 level of significant 
thus suggesting acceptance of the null hypothesis, which states that there is no significant relationship between bank credit allocated to public sector and human development index. The result is in accordance with our apriori expectation, this means for every one percent increase in BCTPS there is an increase of $04.000126 \%$ in HDI, the findings agrees with Sebastian (2018) who discovered that resource misallocation is common in the private sector loan and the loan borrowed to the private sector are not productive as that of other sector, moreover the rate of default from lending to this sector is high compared to other sectors in the economy.

Table 4.

Result of error correction model estimates.

\begin{tabular}{c|c|c|c|c}
\hline Dependent Variable: HDI \\
\hline Variable & Coefficient & Std. Error & t-Statistic & Prob. \\
\hline C & 0.559915 & 0.011090 & 50.48763 & 0.0000 \\
\hline BCTPS & 4.000126 & $2.18 \mathrm{E}-06$ & 1.843775 & 0.0771 \\
\hline BCTREC & 0.000267 & 0.000138 & 1.934380 & 0.0645 \\
\hline BCTMFS & -0.000204 & $6.98 \mathrm{E}-05$ & -2.927948 & 0.0072 \\
\hline BCTAS & 0.000413 & 0.000200 & 2.070099 & 0.0489 \\
\hline BCTMS & -7.121505 & 2.083205 & -3.430389 & 0.0021 \\
\hline BCTGC & -3.832705 & 7.200005 & -0.531699 & 0.5996 \\
\hline ECM(-1) & -0.418358 & 0.185380 & -2.256760 & 0.0330 \\
\hline R-squared & 0.580393 & Mean dependent var & 0.523485 \\
\hline Adjusted R-squared & 0.462903 & S.D. dependent var & 0.059145 \\
\hline S.E. of regression & 0.043346 & Akaike info criterion & -3.232008 \\
\hline Sum squared resid & 0.046971 & Schwarz criterion & -2.869218 \\
\hline Log likelihood & 61.32813 & Hannan-Quinn criter. & -3.109940 \\
\hline F-statistic & 4.939929 & Durbin-Watson stat & 2.133603 \\
\hline Prob(F-statistic) & 0.001303 & \multicolumn{5}{l}{} \\
\hline
\end{tabular}

Secondly, bank credits to real estate and construction has a positive coefficient of 0.000267 alongside a significant $\mathrm{P}$-value of 0.0645 which is greater than 0.05 level of significant thus suggesting rejection of the alternate hypothesis, and accept the null hypothesis which states that there is a significant relationship between bank credits to real estate and construction (BCTREC) and human development index. This implies that for every ne percent increase in (BCTREC) it will lead to about $0.000267 \%$ increase in HDI this result is in accordance with our apriori expectation. The positive relationship is as a result of interest on investment that this form of investment will yield in the long run since it's a capital investment, whereas the negative relationship arises because people don't want to wait for long period of time to get a huge return for the money they have invested. The attitude of people on long term investment in the country is not encouraging, people prefer investing in project that they will get them quick maximum return within a short period of time. Thirdly, bank credit to manufacturing sector exhibited a negative coefficient of -0.000204 alongside a significant P-value of 0.0072 which is less than 0.05 level of significant thus suggesting acceptance of the alternate hypothesis, which states that there is a significant relationship between bank credit allocated to manufacturing sector and human development index, the result did not adhere to our apriori expectation earlier stated, moreover for every one percent increase in loan apportion to manufacturing sector will lead to a decrease of $-0.000204 \%$ in human development index, the positive relationship identified complies with to findings of Ademola and Marshal (2018) but the negative contribution arises as a result of risky business environment in Nigeria, this makes cost of production to be on the increase, the riskiness of this environment also turns away foreign investors, which would have led to growth and development of the economy. Fourthly, following the ECM report bank credit to agricultural sector exhibited a positive coefficient of 0.000413 alongside a significant P-value of 0.0489 which is less than 0.05 level of 
significant thus suggesting acceptance of the alternate hypothesis, which states that there is a significant relationship between bank credit allocated to agricultural sector and human development index, this means for every one percent increase in loan given for agricultural purpose, there is an increase of $0.000413 \%$ in human development index, this result adhere to our apriori expectation as earlier anticipated and the findings of Udoka, Mbat, and Duke (2016) the reasons for positive contribution emanates from improved method of farming, ranging from tractors, ploughs, also there is improvement in the terms storage facility and the mode of transportation have been improved, meanwhile the farmers have a wide range of interaction with the external word in terms of exportation of raw materials, which yield term huge profit in return, this invariably has a positive effect in the production of goods thereby increasing profit, but the insignificant relationship is as a result of collateral demanded by farmers to secure loan facility is very rigorous and this dramatically makes them still depend on the crude implement. While, bank credit to mining sector exhibited a positive coefficient of -7.121505 alongside a significant p-value of 0.0021 which is less than 0.05 level of significant thus suggesting acceptance of the alternate hypothesis, which states that there is a significant relationship between bank credit allocated to mining sector and human development index, for every unit increase in the loan given to them there will be a decrease of $-3.832705 \%$ in its contribution to human development index in the country, this result aggress with the findings of Maxwell (2016). Mining activity takes place in small-scale which provides considerable employment, particularly in rural areas in Nigeria, quiet a large number of persons are employed in the informal small-scale mining, then the formal mining sector, but the loan allocated to this sector cannot adequately cater for the large number of persons in the industry, this in turn reduces output and decreases human development index in the country. Lastly, bank credit allocated to general commerce exhibited a negative coefficient of 03.832705 alongside a significant $\mathrm{P}$-value of 0.5996 which is greater than 0.05 level of significant thus suggesting reject the alternate hypothesis, and accept the null hypothesis which states that there is no significant relationship between bank credit allocated to general commerce and human development index. Because of the various macro-economic disruption, political disruption and most especially because of the volatility in foreign exchange market commercial transactions in the country is on the low side this has made the demand for local commodity to be on the low side.

\subsection{Causality Tests}

From the causality result in Table 5 , it can be seen that BCTAS granger cause BCTPS and BCTPS granger cause BCTAS, this means there is a bi-directional relationship existing between BCTAS and BCTPS. BCTMS and BCTRE, this means past values of BCTMS can be used to predict the future value of BCTRE, same direction of causality exists between BCTGC and BCTMS, likewise BCTMS and BCTGC, this also means that past value of BCTMS can predict the future value of BCTGC vice versa, BCTGC and BCTREC, BCTMFS and BCTREC it also means there is a re-enforcement relationship between the two variables under investigation. A uni-directional relationship was established between BCTREC and BCTPS, this means BCTPS causes a change in BCTREC that is past values of BCTREC can predict the future value of BCTPS, likewise past values of BCTPS cannot be use to predict that of BCTMS. A uni- directional causality is identified between BCTGC and BCTPS, this means past values of BCTGC can predict the future value of BCTPS, but past values of BCTGC cannot predict that of BCTPS. It was also seen that past values of BCTAS can predict changes in BCTREC but BCTREC cannot predict changes in BCTAS, past value of BCTMS can be used to predict BCTMFS but not vice versa, past values of BCTGC can be used to predict BCTGC, past values of BCTMS can be used to predict BCTMS but that of BCTMS cannot predict BCTAS. Lastly, no causal relationship exists between (BCTGC and BCTAS) (BCTREC and HDI) (BCTMFS and HDI) (BCTMFS and HDI) (BCTAS and HDI) (BCTMS and HDI) (BCTGC and HDI) likewise BCTPS and HD, this means past values of BCTPS cannot be use to predict future value of HDI vice versa. 
Table 5.

Result of pairwise granger causality.

\begin{tabular}{|c|c|c|c|}
\hline Null Hypothesis: & Obs & F-Statistic & Prob. \\
\hline BCTPS does not Granger Cause HDI & 32 & 0.04382 & 0.9572 \\
\hline \multicolumn{2}{|l|}{ HDI does not Granger Cause BCTPS } & 1.60667 & 0.2191 \\
\hline BCTREC does not Granger Cause HDI & 32 & 0.19490 & 0.8241 \\
\hline \multicolumn{2}{|l|}{ HDI does not Granger Cause BCTREC } & 0.72795 & 0.4921 \\
\hline BCTMFS does not Granger Cause HDI & 32 & 0.08564 & 0.9182 \\
\hline \multicolumn{2}{|l|}{ HDI does not Granger Cause BCTMFS } & 1.63161 & 0.2143 \\
\hline BCTAS does not Granger Cause HDI & 32 & 0.05480 & 0.9468 \\
\hline \multicolumn{2}{|l|}{ HDI does not Granger Cause BCTAS } & 0.39754 & 0.6758 \\
\hline BCTMS does not Granger Cause HDI & 32 & 0.05112 & 0.9503 \\
\hline \multicolumn{2}{|l|}{ HDI does not Granger Cause BCTMS } & 0.11622 & 0.8907 \\
\hline BCTGC does not Granger Cause HDI & 32 & 0.05967 & 0.9422 \\
\hline \multicolumn{2}{|l|}{ HDI does not Granger Cause BCTGC } & 1.18254 & 0.3219 \\
\hline BCTREC does not Granger Cause BCTPS & 32 & 11.2355 & 0.0003 \\
\hline \multicolumn{2}{|l|}{ BCTPS does not Granger Cause BCTREC } & 21.6702 & 2.0006 \\
\hline BCTMFS does not Granger Cause BCTPS & 32 & 12.4099 & 0.0002 \\
\hline \multicolumn{2}{|l|}{ BCTPS does not Granger Cause BCTMFS } & 10.4538 & 0.0004 \\
\hline BCTAS does not Granger Cause BCTPS & 32 & 7.25977 & 0.0030 \\
\hline \multicolumn{2}{|l|}{ BCTPS does not Granger Cause BCTAS } & 10.8013 & 0.0004 \\
\hline BCTMS does not Granger Cause BCTPS & 32 & 6.18313 & 0.0062 \\
\hline \multicolumn{2}{|l|}{ BCTPS does not Granger Cause BCTMS } & 18.6824 & 8.3206 \\
\hline BCTGC does not Granger Cause BCTPS & 32 & 11.1163 & 0.0003 \\
\hline \multicolumn{2}{|l|}{ BCTPS does not Granger Cause BCTGC } & 17.5699 & 1.0005 \\
\hline BCTMFS does not Granger Cause BCTREC & 32 & 12.3189 & 0.0002 \\
\hline \multicolumn{2}{|l|}{ BCTREC does not Granger Cause BCTMFS } & 3.28246 & 0.0530 \\
\hline BCTAS does not Granger Cause BCTREC & 32 & 5.49754 & 0.0099 \\
\hline \multicolumn{2}{|l|}{ BCTREC does not Granger Cause BCTAS } & 2.14492 & 0.1366 \\
\hline BCTMS does not Granger Cause BCTREC & 32 & 4.37798 & 0.0226 \\
\hline \multicolumn{2}{|l|}{ BCTREC does not Granger Cause BCTMS } & 7.61355 & 0.0024 \\
\hline BCTGC does not Granger Cause BCTREC & 32 & 13.1554 & 0.0001 \\
\hline \multicolumn{2}{|l|}{ BCTREC does not Granger Cause BCTGC } & 10.1588 & 0.0005 \\
\hline BCTAS does not Granger Cause BCTMFS & 32 & 0.87705 & 0.4275 \\
\hline \multicolumn{2}{|l|}{ BCTMFS does not Granger Cause BCTAS } & 4.70691 & 0.0176 \\
\hline BCTMS does not Granger Cause BCTMFS & 32 & 4.03299 & 0.0293 \\
\hline \multicolumn{2}{|l|}{ BCTMFS does not Granger Cause BCTMS } & 17.9736 & 1.1205 \\
\hline BCTGC does not Granger Cause BCTMFS & 32 & 1.20888 & 0.3142 \\
\hline \multicolumn{2}{|l|}{ BCTMFS does not Granger Cause BCTGC } & 6.57586 & 0.0047 \\
\hline BCTMS does not Granger Cause BCTAS & 32 & 1.33920 & 0.2789 \\
\hline \multicolumn{2}{|l|}{ BCTAS does not Granger Cause BCTMS } & 6.94173 & 0.0037 \\
\hline BCTGC does not Granger Cause BCTAS & 32 & 0.94354 & 0.4017 \\
\hline \multicolumn{2}{|l|}{ BCTAS does not Granger Cause BCTGC } & 2.07745 & 0.1448 \\
\hline BCTGC does not Granger Cause BCTMS & 32 & 11.2398 & 0.0003 \\
\hline \multicolumn{2}{|l|}{ BCTMS does not Granger Cause BCTGC } & 5.02244 & 0.0140 \\
\hline
\end{tabular}




\section{Conclusion and Recommendations}

This study examined sectorial allocation of bank credits and economic development in Nigeria using data on human development index as an indicator of economic development and bank credit to public sector, manufacturing, agricultural, mining, real estate and construction, with general commerce sector served as the independent variables. It was observed from the Augmented Dickey Fuller (ADF) test that all the variables are integrated of order one, the result of the analysis of the granger causality test showed that none of the independent variable causes a change in the dependent variable meanwhile bidirectional causal relationship exist between (BCTAS and BCTPS), (BCTAS and BCTPS), (BCTGC and BCTREC), (BCTMFS and BCTREC). The Johannsen co-integration test showed that six (6) cointegrating equation is seen in the Table 3. above. Finally, it was discovered from the result of the error correction model (ECM) that the result in Table 4.

shows that bank credit to public sector exhibited a positive coefficient alongside an insignificant relationship with human development index, bank credit real estate and construction has a positive coefficient alongside a significant with human development index. Thirdly, bank credit to manufacturing sector has a negative but significant relationship with human development index, moreover credit to agricultural sector exhibited a positive and significant relationship with human development index. Bank credit to mining sector exhibited a positive coefficient alongside a significant relationship with human development index. Lastly, bank credit allocated to general commerce exhibited a negative and an insignificant relationship with human development index. The result obtained from the ECM led to the conclusion that the banks credit to private sector has a statistically significant effect on economic development. Generally, it is discovered that the current risky business environment is affecting banks' ability to lend to the manufacturing, mining and general commerce sector which ought to drive development, better ways of making the business environment less risky should be evaluated by stake holders. Based on the above implication of the result of this study, we shall make the following recommendations: The capacity of bank lending is dependent on the magnitude of their deposit, hence there is a need for banks to source for bigger deposits so as to extend more credit to rural farmers in the country, this will invariably contribute to an increase in the standard of living of the people. There should be some special incentives as to lending to private sector by banks, since contribution of the private sector in the country reduces the effect of poverty in the country. Since the contribution of agriculture and manufacturing sectors is largely felt, and they hold a larger percentage of employed citizen in the country, then there is need to encourage better and strong credit culture which will help in sustaining the identified sectors. Monetary authorities should control key macroeconomic factors, this will enable the banking sector to create more credit for the economy. Thereby enhancing investment and employment opportunities which on the other hand will boast economic development in the country.

\section{References}

Ademola, A. F., \& Marshal, O. T. (2018). Financial deepening and the performance of manufacturing firms in Nigeria. Canadian Social Science, 14(6), 87-96.

Adesoye, B. A., Adelowokan, O. A., Maku, E. O., \& Salau, S. O. (2018). Enhancing agricultural value chain for economic diversification in Nigeria. African Journal of Economic Review, 6(1), 103-1 18.

Andabai, P. W., \& Eze, G. (2018). Bank credit and manufacturing sector growth in Nigeria: A causality investigation. International Journal of Economics, Commerce and Management, 6(3), 326-331.

Anyanwu, A. (2000). Research methodology in business and social sciences. Owerri: Canunn Publishers Nigeria Limited.

Bebeji, A. (2010). An assessment of credit management strategies and nonperforming loans of banks in Nigeria. Paper presented at the Paper Presented at a Maiden Annual Conference, Organized by School of Business and Financial Studies, Kaduna Polytechnic.

CBN. (2020). Central Bank of Nigeria 2020 Annual Report. Retrieved from: www.cbn.ng.com/publicstions/annual report. [Accessed 12/08/2020]. 
Ekine, D. I., \& Onukwuru, F. (2018). Deposit money banks' credit and agricultural sector performance in Nigeria. Greener Journal of Agricultural Sciences, 8(3), 65-73.

Ezirim, B. C. (2005). Finance dynamics principles, techniques and applications. Port Harcourt: Published by Markowitz Centre for Research and Development.

Franklin, A., \& Oura, H. (2004). Sustained economic growth and the financial system. institute for monetary and economic research (IMES). Bank of Japan, Discussion Paper No. No. 2004-E-17. Retrieved from: http://www.imes.boj.or.jp. [Accessed 12/08/2020].

Goldsmith, R. W. (1969). Financial structure and development New Haven, CT: Yale University Press.

Levine, R. (2002). Bank-based or market-based financial systems: Which is better? Journal of Financial Intermediation, $11(4), 398-428$.

Maxwell, U. (2016). Sectoral loans demand and performances of deposit money banks in Nigeria. International Journal of Accounting Research, 42(3404), 1-12.

McKinnon, P. (1973). Money and capital in economic development. Washington DC: Brookings Institution.

Michael, S. O., Babatunde, A. O., \& Joseph, N. A. (2017). Bank credit and growth of the manufacturing sector nexus in Nigeria. An ARDL Approach. Euro Economica, Danubius University of Galati, 2(36), 62-72.

Nwakanma, P. C., Nnamdi, I. S., \& Omojefe, G. O. (2014). Bank credits to the private sector: Potency and relevance in Nigeria's economic growth process. Accounting and Finance Research, 3(2), 2335.

Nwanyanwu, O. J. (2011). An analysis of banks credit on the Nigeria economic growth. (1992-2008). Jos Journal of Economics, 1(4), 43-58.

Nzomoi, J., \& Rutto, N. (2012). Assessing the impact of private sector credit on economic performance: evidence from sectoral panel data for Kenya. International Journal of Economics and Finance, 4(3), $182-190$.

Odufuye, B. M. (2007). Imperatives for effective and efficient credit administration in the Banking Sector: Nigerian Banker 28. Retrieved from: https://papers.ssrn.com/sol3/papers.cfm?abstract_id=3055515. [Accessed 12/08/2020].

Okereke, E. J. (2003). Financial deepening and economic development of Nigeria: An empirical investigation. African Journal of Accounting, Economics, Finance and Banking, 5(5), 52-66.

Sebastian, O. U. (2018). Banking system credits to the domestic economy and national development. Annals of University of Bucharest, Economic and Administrative Series, 1(6), 149-164.

Shaw, E. S. (1973). Financial deepening in economic development. New York: Oxford University Press.

Singh, A. (1997). Financial liberalisation, stockmarkets and economic development. The Economic Journal, 107(442), 771-782.

Udoka, C. O., Mbat, D., \& Duke, S. B. (2016). The effect of commercial banks' credit on agricultural production in Nigeria. Journal of Finance and Accounting, 4(1), 1-10. 